\title{
CLARICE LISPECTOR: EVOCAÇÕES DO RECIFE
}

\section{Gilberto Figueiredo Martins ${ }^{(*)}$}

E eu sentia o drama social com tanta intensidade que vivia de coração perplexo diante das grandes injustiças a que são submetidas as chamadas classes menos privilegiadas. Em Recife eu ia aos domingos visitar a casa de nossas empregadas nos mocambos. E o que eu via me fazia como que prometer que não deixaria aquilo continuar. Eu queria agir. Em Recife, onde morei até doze anos de idade, havia muitas vezes nas ruas um aglomerado de pessoas diante das quais alguém discursava ardorosamente sobre a tragédia social. $E$ lembro-me de como eu vibrava e de como eu me prometia que um dia esta seria a minha tarefa: a de defender os direitos dos outros.'

A perplexidade diante do descompasso entre modernização e exclusão social na cidade do Recife, durante os anos 20/30, marca o modo de ver da menina Lispector, que viria a se tornar advogada com o intuito de reformar o sistema penitenciário do país ${ }^{2}$. Seu campo de atuação acabou sendo, entretanto, a literatura, mesmo consciente de que seu ofício em nada contribuiria para alterar tais desigualdades ${ }^{3}$. A

(-) Doutor em Letras (Literatura Brasileira) pela Universidade de São Paulo.

1 O que cu queria ter sido. A descoberta do mundo, p.21.

2 "Como é que cu seria charlatã? Eu fui, e com toda a sinceridade, pensando que acertava. Sou, por exemplo, formada em Direito, e com isso enganei a mim e aos outros. Não, mais a mim que a todos. No entanto, como cu era sincera: fui cstudar Direito porque desejava reformar as penitenciárias no Brasil." (Charlatões. A descoberta do mundo, p.281)

3 Da já tornada célebre entrevista que a escritora concedeu à TV Cultura, extraímos o trecho a seguir:

"LERNER: Em que medida o trabalho de Clarice Lispector [...] pode alterar a ordem das coisas?

CLARICE: Não altera em nada... Não altera $\mathrm{cm}$ nada... Eu escrevo sem esperança que o que escrevo altere qualquer coisa. Não altera em nada..."

(Revista Shalom. São Paulo, ano 27, n.296, p.68, 1992.)

$E$ da crônica $O$ que eu queria ter sido: "Por que foi o destino me levando a escrever o que já escrevi. em vez de também desenvolver em mim a 
urbe, em vez de local por excelência do exercício da sociabilidade e do encontro, começava desde cedo a mostrar-se como palco de luta e cenário de injustiças. Se, por vezes, a escritora viria a reproduzir a retórica que elegia o "interior" do Brasil como reduto de nacionalidade e identidade cultural, no qual a essência regional estaria salvaguardada do avanço tentacular de outras culturas, hegemônicas, por outro lado, desde sempre, percebia criticamente os efeitos das transformações sociais que a metrópole em crescimento sofria e sua contribuição para acentuar traços de diferença e atraso.

A "fome", como experiência metafísica e existencial, destino e condição, ganha nítidos contornos sociais, descendo à terra, como dado e fato concretos e observáveis, produto da injustiça dos homens e "tragédia social" de dimensão nacional: "mas se não sei prever, posso pelo menos desejar. Posso intensamente desejar que o problema mais urgente se resolva: o da fome. Muitíssimo mais depressa, porém, do que em vinte e cinco anos, porque não há mais tempo de esperar: milhares de homens, mulheres e crianças são verdadeiros moribundos ambulantes que tecnicamente deviam estar internados em hospitais para subnutridos. Tal é a miséria, que se justificaria ser decretado estado de prontidão, como diante de calamidade pública. Só que é pior: a fome é a nossa endemia, já está fazendo parte orgânica do corpo e da alma. E, na maioria das vezes, quando se descrevem as características físicas, morais e mentais de um brasileiro, não se nota que na verdade se estão descrevendo os sintomas físicos, morais e mentais da fome."

Os contos e crônicas mais eminentemente autobiográficos, mas também outros nos quais a infância aparece tematizada, servem para complementar - como depoimentos ficcionalizados - uma visão sobre

qualidade de lutadora que eu tinha? [...] o que terminei sendo, e tão cedo? Terminei sendo uma pessoa que procura o que profundamente se sente e usa a palavra que o exprima. É pouco, muito pouco" (p. 21/22).

Finalmente, no texto A entrevista alegre, Clarice comenta uma resposta sua dada a uma entrevistadora: "Perguntou-me o que eu achava da literatura engajada. Achei válida. Quis saber se eu me engajaria. Na verdade sinto-me engajada. Tudo o que escrevo está ligado, pelo menos dentro de mim, à realidade em que vivemos. É possível que este meu lado ainda se fortifique mais algum dia. Ou não? Não sei de nada. Nem sei se escreverei mais. É mais possível que não" (A descoberta do mundo, p. 60). 
modos peculiares de subjetivação e algumas das relações de sociabilidade vivenciadas na cidade brasileira, nas primeiras décadas do século XX.

No conto "Felicidade clandestina", escrito em primeira pessoa e ambientado "nas ruas de Recife" - "onde morávamos, com suas pontes mais do que vistas" -, ocorre o embate entre a narradora e uma menina mais rica, filha de um dono de livraria. O dito popular sobre a injusta realidade daqueles que têm dentes e não querem ou não podem comer sofre desdobramentos figurados numa impiedosa luta, na qual a detentora de maior poder financeiro - e que aparentemente "pouco aproveitava" do que estava a sua disposição - humilha perversamente a submissa menina pobre, para quem os livros estavam "completamente acima de suas posses". A disparidade de condições econômicas é reforçada no contraste da caracterização física das personagens: a menina, filha do comerciante, é desenhada com as tintas do excesso, em tudo superlativa - é "gorda", tem "cabelos excessivamente crespos", o "busto enorme", traz sempre os "bolsos cheios de balas", escreve com "letra bordadíssima" e exerce, calculadamente, sua "crueldade" e "sadismo", voltando contra a futura narradora sua "potência de perversidade", exercitando meticulosa e sistematicamente, como em um rito indefinidamente renovável, sua "vingança", "enquanto o fel não escorresse todo de seu corpo grosso". Já a narradora-personagem aparece, como suas outras companheiras, sem busto, "ainda achatadas", "imperdoavelmente bonitinhas, esguias, altinhas", de cabelos livres". "Humilde e silenciosa", humilhada e implorante, submete-se aos caprichos sádicos de sua vingativa torturadora, consciente das impossibilidades impostas por sua condição de classe, mas sempre perseverando, desejante.

Como marca da falta, a premente "ânsia de ler" de uma pobre "criança devoradora de histórias", fome amplificada pela promessa que o objeto desejado traz de satisfação e fartura: o livro As reinações de Narizinho, de Monteiro Lobato, "era um livro grosso, meu Deus, era um livro para se ficar vivendo com ele, comendo-o, dormindo-o".

4 O conto encontra-se no volume homônimo. Em $A$ descoberta do mundo, o texto reaparece, como crônica, com algumas modificações, e sob o título Tortura e glória.

5 Note-se a ironia no uso dos diminutivos para a auto-referência como elementos contrapontísticos à caracterização superlativa da filha do dono da livraria. 
Porém, a inacessibilidade é reafirmada na forma de "tortura chinesa" e os futuros temas literários do adiamento e da recusa e resistência sempre gritadas pelo mundo ganhavam ali os primeiros contornos da experiência: "[...] o dia seguinte viria, os dias seguintes seriam mais tarde a minha vida inteira, o amor pelo mundo me esperava [...]. Mal sabia eu como mais tarde, no decorrer da vida, o drama do 'dia seguinte' com ela ia se repetir com meu coração batendo", "A promessa de que "o amor pelo mundo [a] esperava", como possibilidade de participação, satisfação e preenchimento, faz com que se anule temporariamente a condição de manca da narradora: "andei pulando pelas ruas como sempre" - "que era meu modo estranho de andar pelas ruas de Recife" -, mas, então, surpreendentemente, "não caí nenhuma vez".

A "vingança" da menina gorda se compraz na luta e na exposição de armas; do mesmo modo como ruidosa e provocativa chupava as balas, a algoz exibe sua superioridade e o poder de manipular o desejo da outra, prometendo e adiando, atraindo e negando, meticulosamente oferecendo o que sabe a açúcar para poder impiedosamente petrificar e anular ${ }^{7}$. O jogo perverso da satisfação

6 Em uma crônica publicada no Jornal do Brasil, Clarice refere-se novamente ao fato biográfico que serve de motivo ao conto: "Tive várias vidas. Em outra de minhas vidas, o meu livro sagrado foi emprestado porque era muito caro: Reinações de Narizinho. Já contei o sacrifício de humilhações e perseveranças pelo qual passei, pois, já pronta para ler Monteiro Lobato, o livro grosso pertencia a uma menina cujo pai tinha uma livraria. A menina gorda e muito sardenta se vingara tornando-se sádica e, ao descobrir o que valeria pra mim ler aquele livro, fez um jogo de amanhã venha em casa que eu empresto. Quando eu ia, com o coração literalmente batendo de alegria, ela me dizia: Hoje não posso emprestar, venha amanhã. Depois de cerca de um mês de venha amanhã, o que eu, embora altiva que era, recebia com humildade para que a menina não me cortasse de vez a esperança, a mãe daquele primeiro monstrinho de minha vida notou o que se passava e, um pouco horrorizada com a própria fillha, deu-lhe ordens para que naquele mesmo momento me fosse emprestado o livro. Não o li de uma vez: li aos poucos, algumas páginas de cada vez. para não gastar. Acho que foi o livro que me deu mais alegria naquela vida" (O primeiro livro de cada uma de minhas vidas. A descoberta do mundo, p.722).

7 O mesmo processo reconfigura-se como rito no conto de Lispector $A$ quinta história. 
negada, "plano secreto", "tranqüilo e diabólico", que se mantém pelo adiamento interminável que marca o mal infinito, se manifesta pela via da possessão hipnótica: "olhando bem para os [seus] olhos", a gorda de novo espremia pela cintura, esmagava de leve, adiando o momento da morte, gozando perversamente com o sofrimento da outra, à qual resta quedar-se paralisada e "boquiaberta", sentindo as olheiras "se cavando sob os [seus] olhos espantados".

Sendo o processo, graças ao acaso, interrompido pela intervenção da mãe da oponente, a narradora vê-se de posse do objeto, "pelo tempo que quisesse". O adiamento da leitura será agora ousada estratégia de gozo, a usura e a economia garantindo o controle planejado da satisfação parcial de uma fome permanente ${ }^{8}$. A espera controlada, dominada, renovada e voluntária impede a realização plena que esgota e mata o desejo, sendo colocada em estado de suspensão e contenção, por tempo indefinido, a experiência de ter o que é alheio. A plebéia "menina loira" pode, com "orgulho e pudor", metamorfosear-se imaginariamente em "rainha delicada", adiando a felicidade clandestina, "indo comer pão com manteiga" no lugar de satisfazer a fome maior. Como quem se vê frente a objeto sagrado, vive o livro, "sem tocá-lo, em êxtase puríssimo", para depois devorálo, num rito de iniciação - "Não era mais uma menina com um livro; era uma mulher com o seu amante"

s Em A paixão segundo $G$. H., a narradora e protagonista faz referência ao "prazer avaro e permanentemente promissor de ter e não gastar", como paradoxal estratégia de gozo e controle.

9 A imagem da "rainha delicada" parece, ainda, referir ao título do livro cobiçado/conquistado: a posse do objeto permite, finalmente, que a menina também possa "reinar", como a personagem de Monteiro Lobato.

10 Como se vê, para a jovem Lispector, desde sempre, a literatura se constituía uma possibilidade de diálogo e de resposta. Na mesma crônica - O primeiro livro...-, conta o que vivenciou ao ler alguns outros livros: com a releitura das historinhas do patinho feio e da lâmpada de Aladim em um "livro fininho" no entanto considerado pela menina uma "preciosidade" - aprendia, respectivamente, que por trás dos sofrimentos de um pato feio e rejeitado por ser diferente escondia-se o "mistério" da transfiguração em cisne ("quem sabe se eu era um cisne?"), e que também ela era "crédula" às "lonjuras do impossível", apesar de tudo: "o impossível naquela época estava ao meu alcance. A idéia do gênio que dizia: pede de mim o que quiseres, sou teu servo - isso me fazia cair em devaneio. Quieta no meu canto, eu pensava se algum dia um gênio me 
A evocação do Recife continua em outro conto, também de fundo autobiográfico, "Restos do carnaval"" . Nele, encontram-se destacados os signos de morte que a narradora guarda na memória como marcas permanentes da infância e da festa pagã. O texto iniciase com uma dupla negação, exibindo como cenário recordado a paisagem de uma quarta-feira de cinzas de um carnaval na capital pernambucana, dia que deixa "mortas" e "extremamente vazias" as ruas da cidade, nas quais esvoaçavam "despojos de serpentina e confete". Transportada no tempo, a adulta revisita as cinzas e ruínas, a solidão, o vazio e os dejetos ("restos") com que se marcava o fim da ilusão e da folia. Mas, sendo a infância ainda um foco de resistência, tempo da fantasia e espaço do desejo, era então possível naqueles momentos ao menos experimentar certa "agitação íntima" que precedia os festejos:

Como se enfim o mundo se abrisse de botão que era em grande rosa escarlate. Como se as ruas e praças do Recife enfim explicassem para que tinham sido feitas. Como se vozes humanas enfim cantassem a capacidade de prazer que era secreta em $\mathrm{mim}^{12}$.

Se no trecho acima a repetição do advérbio "enfim" enfatiza a possibilidade de realização e abertura que justificava uma espera

diria: Pede de mim o que quiseres. Mas desde então revelava-se que sou daqueles que têm que usar os próprios recursos para terem o que querem, quando conseguem" (A descoberta..., p.721/2, com grifos meus).

Aos quinze anos, entra em uma livraria, "com o primeiro dinheiro ganho por trabalho" seu e, "altiva porque tinha dinheiro", descobre lá "o mundo onde [...] gostaria de morar" e, finalmente, uma alma gêmea:

Folheei quase todos os livros dos balcões, lia algumas linhas e passava para outro. E de repente, um dos livros que abri continha frases tão diferentes que fiquei lendo, presa, ali mesmo. Emocionada, eu pensava: mas esse livro sou eu! E, contendo um estremecimento de profunda emoção, comprei-o. Só depois vim a saber que a autora não era anônima, sendo, ao contrário, considerada um dos melhores escritores de sua época: Katherine Mansfield.

11 Em Felicidade clandestina.

12 A confissão - feita pela adulta - de um segredo de menina retoma os temas da interdição, do inacessível, do proibido e da clandestinidade, denunciando a dimensão trágica da experiência existencial que responde criticamente ao propalado mito da infância feliz. 
angustiante, vem entretanto acompanhada da expressão "como se" no início dos três períodos, a qual denuncia a dimensão fantasiosa da felicidade estampada nas cores e vozes "humanas", mas de novo dos outros, como ecos externados daquilo que no sujeito é "secreto" porque interdito, clandestino, motivo de culpa e auto-repreensão. Ao fim, a festa popular é ansiada por trazer não só a ilusão temporária da participação como a da posse, da propriedade: "Carnaval era meu, meu".

E se o primeiro parágrafo do conto abre-se com os dois não, o segundo os reforça, instaurando uma dupla adversidade, como dura certeza: "No entanto, na realidade, eu dele pouco participava. Nunca tinha ido a um baile infantil, nunca me haviam fantasiado". A única "compensação" era poder ficar à noite, "à porta do pé de escada do sobrado onde morávamos, olhando ávida os outros se divertirem", mais uma vez voraz espectadora do alheio. E, assim como em "Felicidade clandestina", a consciência do prazer como experiência exaurível gera as precauções da economia e da "avareza": um único frasco de lança-perfume e um saco de confete teriam que durar os três dias da festa.

Tratando dos escritos de temática autobiográfica de autores como Walter Benjamin, Graciliano Ramos e Clarice, Maria do Carmo Campos chama a atenção para os movimentos da recordação, tornada matéria literária, graças aos quais "a memória adulta encontra o espaço do vivido, no que ele foi de descoberta, anseio e tortura".". Nesse conto, a adulta "que recorda e escreve" rememora a experiência da infância pobre no Recife como triste lembrança. Os "restos", os dejetos e as sobras - o "quase nada" que é compensação provisória da falta - reaparecem como travo, a lembrar e confirmar insistentemente as exigências de uma condição. E, assim, a memória afetiva atrasa o relato:

Ah, está se tornando difícil escrever. Porque sinto como ficarei de coração escuro ao constatar que, mesmo me agregando tão pouco à alegria, eu era de tal modo sedenta que um quase nada já me tornava uma menina feliz.

A "capacidade de prazer" da menina, força renovada anualmente pela "agitação íntima" que precedia os festejos do

13 Campos (1999, p.200-212). 
carnaval, soma-se aos sustos e ao "medo vital e necessário" nascidos do "contato indispensável" com as máscaras e mascarados da festa popular, os quais, quando por ela fitados, a reconduzem reflexivamente - a seu "mundo interior", feito de "pessoas com o seu mistério" e seus rostos-máscaras. Duplo movimento de expansão e retração; olhar o outro é também olhar-se no outro. Em sua casa, já sabemos, nunca a fantasiavam, preocupados que estavam todos com a doença de sua mãe: "ninguém em casa tinha cabeça para carnaval de criança". A vaidade, porém, incômoda mas também vital, reafirma-se, remetendo ao "sonho intenso de ser moça", desejo que, se realizado, propiciaria a ansiada "saída de uma infância vulnerável". Mas, enquanto não se efetivava o processo orgânico e natural, a festa oferecia a possibilidade de uma metamorfose simulada e passageira ${ }^{14}$ : "[...] eu pedia a uma de minhas irmãs para enrolar aqueles meus cabelos lisos que me causavam tanto desgosto e tinha então a vaidade de possuir cabelos frisados pelo menos durante três dias por ano". A fantasia da individuação atingida na transformação temporária do pato em cisne, ou do "botão" em "grande rosa escarlate", viabiliza-se e ganha corpo pelo uso da máscara (ainda que não se disfarce o aparente exagero próprio do que é postiço) ${ }^{15}$ : “[...] e pintava minha

14 O desejo de transformação em outra coisa ou pessoa e a presença de uma personagem estilista/costureira aproximam, intertextualmente, o conto de Clarice e o episódio A Costureira das Fadas, do livro de Lobato mencionado no conto anterior. E, obviamente, aos clássicos Cinderela e $A$ Gata Borralheira. Cf. LOBATO, Monteiro. Reinações de Narizinho no Reino das Águas Claras. 1998 (p. 25/27).

Em Uma aprendizagem ou O livro dos prazeres, a protagonista Lóri decide ir a uma festa para conseguir um amante e sentir-se madura e mulher. Para tanto, se transfigura - ou desfigura - com "a máscara de palhaço da pintura excessiva": "[...] pintou demais os olhos e demais a boca até que seu rosto branco de pó parecia uma máscara: ela estava pondo sobre si mesma alguém outro [...]. Esse alguém era exatamente o que ela não era. [...] O modo como o chofer olhou-a fê-la adivinhar: ela estava tão pintada que ele provavelmente tomara-a como uma prostituta. Persona. Lóri tinha pouca memória, não sabia por isso se era no antigo teatro grego ou romano que os atores, antes de entrar em cena, pregavam ao rosto uma máscara que representava pela expressão o que o papel de cada um deles iria exprimir. Lóri bem sabia que uma das qualidades de um ator estava nas mutações sensíveis do rosto, e que a máscara as esconderia. Por que então the agradava tanto a idéia de atores entrarem no palco sem rosto próprio? Quem sabe ela achava que a máscara era um 
boca de batom bem forte, passando também ruge nas minhas faces. Então eu me sentia bonita e feminina, eu escapava da meninice".

Até que houve "um carnaval diferente dos outros. Tão milagroso que eu não conseguia acreditar que tanto me fosse dado, eu, que já aprendera a pedir pouco." Como no outro conto, a narradora, "boquiaberta", descobre um tesouro; agora não mais um livro, mas uma fantasia de carnaval feita de papel crepom. Quem a possui, no entanto, é sua amiga. O texto passa a estabelecer um jogo ambíguo com o vocábulo "fantasia", cujo sentido desliza continuamente entre a roupa carnavalesca e a criação imaginária, permitindo que a menina pobre e cobiçosa experiencie fantasiosamente a posse material e a realização do desejo de se tornar moça e de ser outra que não ela ${ }^{16}$ : "Boquiaberta, eu assistia pouco a pouco à fantasia tomando forma e se criando. Embora de pétalas o papel crepom nem de longe lembrasse, eu pensava seriamente que era uma das fantasias mais belas que jamais vira." O milagre nesse carnaval do passado ocorre por força do acaso: sobra papel crepom - "e muito" - da fantasia da amiga e a mãe desta resolve fazer uma outra fantasia de rosa:

E a mãe de minha amiga - talvez atendendo a meu apelo mudo, ao meu mudo desespero de inveja, ou talvez por pura bondade, já que sobrara papel - resolveu fazer para mim também uma fantasia de rosa com o que restara de material. Naquele carnaval, pois, pela primeira vez na vida eu teria o que sempre quisera: ia ser outra que não eu mesma.

dar-se tão importante quanto o dar-se pela dor do rosto. Inclusive os adolescentes, que eram de rosto puro, à medida que iam vivendo fabricavam a própria máscara. E com muita dor. Porque saber que de então em diante se vai passar a representar um papel era de uma surpresa amedrontadora. Era a liberdade horrivel de não-ser. E a hora da escolha. [...] Escolher a própria máscara era o primeiro gesto voluntário humano. E solitário. Mas quando enfim se afivelava a máscara daquilo que se escolhera para representar-se e representar o mundo, o corpo ganhava uma nova firmeza, a cabeça podia às vezes se manter altiva como a de quem superou um obstáculo: a pessoa era" (p.83/86, com grifo meu).

16. No derradeiro romance $A$ hora da estrela, o narrador Rodrigo S. M. "(Na verdade Clarice Lispector)" regozija-se: "A ação desta história terá como resultado minha transfiguração cm outrem e minha materialização enfim em objeto." (p.20) 
[...] Quanto ao fato de minha fantasia só existir por causa das sobras de outra, engoli com alguma dor meu orgulho que sempre fora feroz, e aceitei humilde o que o destino me dava de esmola.

Nos dois contos, a protagonista experimenta a descoberta dolorosa da hierarquia social e da diferença de classes. Em "Felicidade clandestina", a menina gorda e antagonista agiria, segundo a narradora, impulsionada por uma reação vingativa e hostil a atributos que as outras meninas - bonitas, altas, esguias e de cabelos livres apresentavam. Em contrapartida, possuía, mais do que um objeto precioso, uma fonte renovável de objetos garantidores de gozo: tinha não apenas um livro, mas um pai dono de livraria. Tal privilégio era, então, acintosa e perversamente proclamado; e será, projetivamente, compreendido, interpretado e redito como intenção secreta de prejudicar e, o pior, como intenção que encontra à disposição os meios de se realizar, potência traduzida em ato. Da consciência de que uma outra pessoa possui, com exclusividade, algo que garantiria uma gratificação pulsional, uma fonte inesgotável de prazer do qual se vê irremediavelmente privada, nasce a inveja da menina, que futuramente se vingará, por meio da narração judiciosa, sentença tornada pública. Seu incômodo maior vem de perceber a facilidade com que a outra dispensa o dom inacessível, pois de seu atributo "pouco aproveitava", a não ser como arma com a qual exercitava "com calma ferocidade", seu ódio. Este seu maior crime, imperdoável: não se nutrir do oferecido abundantemente pela máquina inexaurível que engendrava quantidades ilimitadas do apetecível e que satisfaria "qualquer criança devoradora de histórias".

Já "Restos de carnaval" traz a diferença social não tão explicitamente como luta ou rivalidade, pois agora se trata de duas amigas, ligadas pelo laço da afetividade. No primeiro conto, a protagonista queria não apenas o objeto suporte da inveja - o livro -, mas privar sua oponente dele, como forma de punição pelo desperdício. E, mais do que o objeto real, concreto, invejava a satisfação - real e imaginária - oferecida pela origem de tudo: um pai proprietário. No texto no qual a narradora rememora o carnaval da infância vivida em Recife, sabemos renovar-se anualmente uma "agitação íntima" que denuncia, como traço mnésico, uma excitação vivida, uma sensação ou percepção prazerosa que pede renovação. $\mathrm{O}$ objeto da inveja será, mais uma vez, menos o suporte concreto - a 
roupa colorida - do que a própria fonte, a mãe estilista e sua capacidade infinita de criar e construir ${ }^{17}$. Daí o fato de a menina fitar ${ }^{18}$, alucinada, sedenta e "boquiaberta", "a fantasia tomando forma e se criando". Nos dois contos, o que a menina - futura escritora inveja é a inquietante capacidade de engendrar, o dom inacessível da (oni)potência de criação e do poder de auto-satisfação, suposto inesgotável e infinito. E nisso os dois objetos, nos dois contos, se assemelham: livro de histórias e roupa de crepom, embora perecíveis, são sinais inequívocos da possibilidade de satisfação e realização, provas materiais de ser possível mascarar-se para viver como outro,

17 "O seio bom que nutre e inicia a relação de amor com a mãe é o representante da pulsão de vida e é também sentido como a primeira manifestação da criatividade. Nessa relação fundamental, o bebê não apenas recebe a gratificação desejada, mas também sente que está sendo mantido vivo. Pois a fome, que suscita o medo de morrer de inanição, e possivelmente suscita até mesmo toda dor psíquica e física, é sentida como ameaça de morte. Se a identificação com um objeto internalizado bom e propiciador de vida puder ser mantida, ela se torna uma força propulsora para a criatividade. Embora superficialmente isso possa manifestar-se como cobiça por prestígio, riqueza e poder que outros tenham alcançado, seu objetivo real é a criatividade. A capacidade de dar e preservar a vida é sentida como o dom máximo e, portanto, a criatividade torna-se a causa mais profunda de inveja" (KLEIN, 1991, p.233, em Inveja e gratidão).

18 Em seus textos, Renato MEZAN reforça sempre a "dimensão visual da inveja", a vinculação entre o olhar e o sentimento invejoso, lembrando, inclusive, a própria etimologia da palavra: "Segundo uma antiga etimologia, "inveja faz com que não seja visto o que deve ser visto, e por isso se chama inveja (invidia), ou seja, não-visão"' (1995, p. 222, nota 3). A idéia de Mezan é confirmada nos escritos de Melanie KLEIN (1991, p.212, nota 6):

"Dr. Elliott Jaques chamou minha atenção para a raiz etimológica de inveja no latim invidia, que provém do verbo invideo - o olhar atravessado, olhar maldosamente ou com despeito, lançar mau-olhado, invejar ou relutar mesquinhamente em dar ou reconhecer o que é do outro. Um uso antigo pode ser encontrado numa expressão de Cícero, cuja tradução é causar infortúnio pelo mau-olhado." No conto, aliás, a narradora, já adulta, rememora sua visão turvada pela alucinação da cobiça: "Embora de pétalas o papel crepom nem de longe lembrasse, eu pensava seriamente que era uma das fantasias mais belas que jamais vira". 
num mundo outro, alucinatório, inventado e recriado, sempre renovado e renovável ${ }^{19}$.

Vemos realizar-se em ambos os textos, como ritual, a passagem da "infância vulnerável" a um estágio superior de maturação e desenvolvimento psíquico-sexual. Embalando-se na rede, a menina de "Felicidade clandestina" une-se ao livro grosso e metamorfoseiase, como por encantamento, em uma "mulher com seu amante"20. No outro conto, mesmo já "desencantada" em sua fantasia deslocada, a menina é reconhecida e se reconhece como rosa, flor desabrochada, por um "menino de uns doze anos", um "rapaz" "muito bonito", príncipe que, magicamente, "numa mistura de carinho, grossura, brincadeira e sensualidade", cobre de confete seus cabelos de menina,

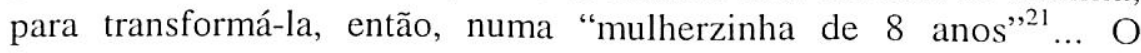

19 No fragmento Fidelidade, de A descoberta do mundo (p.142), lemos: "Quanto a mim, continuo a ler Monteiro Lobato. Ele deu iluminação de alegria a muita infância infeliz. Nos momentos difíceis de agora, sinto um desamparo infantil, e Monteiro Lobato me traz luz."

20

A narradora adulta parece revisitar - rememorando experiências de sua pré-adolescência - os estágios do desenvolvimento infantil, tal como descritos por Freud. Assim, a pulsão de devorar histórias, o sentimento de inveja pelos seios grandes da mãe má (encarnada pela oponente gorda) e a espera angustiada que a faz quedar-se "boquiaberta" ansiando a satisfação de um desejo insaciável figurariam, tornadas ficção, as fixações da fase ou estádio oral; obtida a gratificação, com a posse do objeto garantidor de prazer, os repetidos atos de esconder, adiar e reter, liberar e fruir, dominar e possuir, renovariam, presentificando-os, os sádicos jogos libidinais próprios à fase anal; finalmente, a caminho da individuação e da maturação psíquico-sexual, a menina metamorfoseia-se em mulher e o grosso objeto fálico assume o papel de substituto e passa a ser visto e vivido como nova - e agora acessível - gratificação libidinal, metonimicamente representando o primeiro amante, alcançado enfim o estádio genital.

21 Em crônica de motivo autobiográfico - As grandes punições, de A descoberta do mundo -, Clarice lembra a época em que estudou no "Jardim da Infância do Grupo Escolar João Barbalho, na Rua Formosa, em Recife", período em que conheceu o menino que se tornaria um famoso matemático brasileiro, Leopoldo Nachbin. E rememora, confessional: "Leopoldo - além de meu pai - foi o meu primeiro protetor masculino, e tão bem o fez que me deixou para o resto da vida aceitando e querendo a proteção masculina [...]" (p.41). 
processo de individuação ocorre de maneira semelhante nos dois casos. Ao menos no mundo fantástico e fantasioso da literatura e da festa folclórica, os desejos podem ser realizados ${ }^{22}$, restaurando-se parcialmente uma percepção prazerosa de identificação e pertença, reconstruída sobre um fundo de Falta. Milagrosamente, por meio da fantasia ${ }^{23}$, surge a "salvação" 24 , pela realização temporária e parcial do desejo de coincidência, plenitude, preenchimento, encontro do e pelo outro $^{25}$. Na arte repousa, ao fim e ao cabo, a promessa de felicidade.

No primeiro texto, a imagem de uma mãe má que priva deliberadamente a criança da satisfação de sua avidez e voracidade é projetada na menina ruiva e gorda, de "busto enorme", o qual, aliás, é ampliado pelas inúmeras balas também garantidoras da satisfação oral. O seio - duplamente desejado pela menina esguia, como aporte imaginário de alimento e índice ostensivo de uma maturação sexual e libertadora ainda não atingida por ela - reveste-se da carga simbólica de objeto mau, contra o qual se voltam as fantasias agressivas, e será posteriormente substituído pelo livro-falo-grosso do pai, o qual pode garantir também - por outra via - a satisfação e a realização de fantasias, como compensação para privações internas e externas.

É preciso não esquecer, entretanto, outra afirmação, para pensar no papel do afeto e da diferença de gêneros para a configuração de uma especial relação de sociabilidade: "O homem, este meu igual que me tem assassinado por amor, e a isto se chama de amar, e é" (A favor do medo, em A descoberta do mundo, p.43).

22 Parece retornar, obrigatoriamente, a referência feita $\mathrm{em}$ nota anterior sobre os motivos e temas dos livros infantis $O$ patinho feio e Aladim, primeiras leituras da escritora...

23. "O desejo é assim definível por sua característica intrinsecamente fantasmática, e é por isso que a fantasia será o correlato do desejo, seu cenário, seu roteiro $e$ sua realização. Na fantasia, como no sonho, os desejos não precisam se realizar porque já estão sempre realizados: fantasiar e sonhar são realizações de desejo, independentemente de seu conteúdo específico" (MEZAN, 1995, p.82).

24 Lê-se, em Restos do carnaval: "Só horas depois é que veio a salvação. E se depressa agarrei-me a ela é porque tanto precisava me salvar."

25 Melanie KLEIN (1991, p.230, Inveja e gratidão) ensina que a mudança de desejos orais para desejos genitais reduz positivamente a importância da mãe como provedora de satisfação, possibilitando uma redução no sentimento de inveja e capacitando à busca e ao encontro de novos objetos de amor. 
A "menina devoradora de histórias" revive, como angústia e ansiedade - nostálgicas -, uma necessidade experimentada e satisfeita outrora e agora dirigida, sob a forma de desejo, a um objeto substituto também supostamente inexaurível ("Era um livro grosso, meu Deus") e sempre presente ("era um livro para se ficar vivendo com ele, comendo-o, dormindo-o") ${ }^{26}$. A "tortura chinesa" deriva, contudo, de uma reafirmada experiência de privação (o livro está sempre indisponível para empréstimo) e de uma frustração renovada (por força de outrem que a está deliberadamente privando do que a satisfaria) $)^{27^{3}}$.

Nos dois contos, a angústia cessa exatamente quando a figura da "mãe boa" providencia a satisfação da necessidade e a realização do desejo: a mãe da menina ruiva empresta o livro por tempo

$26 \mathrm{Em}$ Os efeitos das situaçōes de ansiedade arcaicas sobre o desenvolvimento sexual da menina, Melanie KLEIN (1997, p.215) afirma: "Quando a menina se volta para o pênis do pai como objeto desejado, diversos fatores determinam a intensidade do seu desejo. As exigências de seus impulsos orais de sugar, aumentadas pela frustração que ela sofreu ao seio da mãe, criam em sua fantasia um quadro do pênis do pai como um órgão que, ao contrário do seio, pode provê-la com uma satisfação oral tremenda e infinita."

Talvez seja possível afirmar, na esteira do pensamento de Freud c, principalmente, de Melanie Klein, que a necessidade da menina nos dois contos retoma e mobiliza uma necessidade correspondente, própria da primeira infância, de obter provas constantes do amor da mãe. O momento da infância em que, por excelência, se daria essa experiência de participação e plenitude é o da amamentação, durante o período do aleitamento materno, importando aí não apenas a satisfação oral, mas o olhar afetivo e de acolhimento trocado entre mãe e filho, olhos e boca como instrumentos radicais de identificação e reconhecimento. Não à toa, em Felicidade clandestina, o movimento que reproduz o do embalo no colo ou no berço reaparece duas vezes, sempre ligado à satisfação ou, ao menos, a sua promessa: ao pensar que, no dia seguinte, teria o livro emprestado pela oponente ruiva, a protagonista sente-se nadando "devagar num mar suave", com ondas que a levavam e traziam; quando finalmente o possui, senta-se na rede, balançando-se com o livro no colo, "em êxtase puríssimo". A referência, no segundo conto, ao estado debilitado de saúde da mãe da narradora reforça o sentimento vivido de privação e frustração.

Utilizo, no comentário sobre os dois textos, especialmente os conceitos psicanalíticos e as reflexões desenvolvidos nos textos de KLEIN e MEZAN, indicados na bibliografia. 
indeterminado e a mãe da amiga, por "bondade", resolve dar "de esmola" uma roupa igual àquela que criara para a própria filha. Tudo estaria bem, não fosse o fato essencial de que a mãe boa existe, mas... é sempre de outra. Ao fim, parece ser esse o verdadeiro objeto da inveja da protagonista: pais - tornados fantasmáticos - que atendam a suas necessidades e demandas, internas e externas, imaginárias e concretas.

No segundo conto, a amiga aparece ressignificada imaginariamente como uma espécie de irmã, invejada porque alvo exclusivo do amor, da atenção e dos privilégios oferecidos pela "mãe boa". A "mãe má", aqui, é a verdadeira, que, doente e cúmplice do "destino" e do acaso, impede a menina de festejar seu primeiro carnaval "de fantasia" e de encontrar na rua as outras pessoas mascaradas e seus mistérios:

Muitas coisas que me aconteceram tão piores que estas, eu já perdoei. No entanto essa não posso sequer entender agora: o jogo de dados de um destino é irracional? E impiedoso. Quando eu estava vestida de papel crepom todo armado, ainda com os cabelos enrolados e ainda sem batom e ruge - minha mãe, de súbito, piorou muito de saúde, um alvoroço repentino se criou em casa e mandaram-me comprar depressa um remédio na farmácia. Fui correndo vestida de rosa - mas o rosto ainda nu não tinha a máscara de moça que cobriria minha tão exposta vida infantil -, fui correndo, correndo, perplexa, atônita, entre serpentinas, confetes e gritos de carnaval. A alegria dos outros me espantava ${ }^{28}$.

Assim, mesmo depois da melhora da mãe, a alegria e a "fome de sentir êxtase" turvam-se e tingem-se com as sombras da culpa ${ }^{29}$ : "[...] alguma coisa tinha morrido $\mathrm{em} \mathrm{mim}^{30}$. E, como nas histórias que eu havia lido sobre fadas que encantavam e desencantavam pessoas,

${ }^{28}$ Volta aqui o tema do descompasso com o mundo: enquanto todos festejam, ela está triste e espantada e, o que é pior, os outros nem a percebem, impedidas a coincidencia e a solidariedade. Ao final, por estar distraída e desistente, aparece o rapaz-príncipe-salvador...

29 Na crônica As grandes punições, Clarice afirma, como lembrança da infância: "Inútil: eu era a culpada nata, aquela que nascera com o pecado mortal" (p.41)

30 Note-se que, embora não tenha havido o falecimento real da mãe, para a narradora a morte de algo anteriormente sentido como bom é depressivamente experimentada, como vivência interior. 
eu fora desencantada; não era mais uma rosa, era de novo uma simples menina. Desci até a rua e ali de pé eu não era uma flor, era um palhaço pensativo de lábios encarnados. Na minha fome de sentir êxtase, às vezes começava a ficar alegre mas com remorso lembravame do estado grave de minha mãe e de novo eu morria." 31

Já no conto "Cem anos de perdão" 32 , verifica-se um avanço importante no processo de individuação: agora, a menina não dependerá do acaso e da disposição bondosa de outro para satisfazer sua necessidade e para obter o que deseja; partirá para a ação, como "boa realizadora" e, o mais importante - porque um tema recorrente na produção de Clarice - pela via do mal, do crime, da negatividade. Começa a se manifestar já na infância a resposta de recusa a um mundo constituído pelo mal social, pela cruel desigualdade, contra o qual reagirá futuramente a escritora na sua opção insultuosa e provocativa pelo Mal, maiúsculo, como paradoxal forma de redenção, única possível ${ }^{33}$.

Nesse conto, o título retoma - pela via do corte e da ausência que pede a participação ativa do leitor na construção do sentido - o dito popular com o qual se afirma que "ladrão que rouba ladrão tem cem anos de perdão". Com a leitura da narrativa, os dois pólos da assertiva cristalizada evidenciam-se: o ladrão que rouba é a narradora, quando menina; e a suposta vítima - cujas verdadeiras alcunha e condição são atribuídas, maliciosamente, no subentendido do título do conto - é a gente que mora "nas ruas dos ricos" do Recife, "ladeadas por palacetes que ficavam no centro de grandes jardins", ruas de pouquíssimos "transeuntes", por onde "não passavam bondes e raro era o carro que aparecia". O crime - o roubo de rosas - fica, assim,

31 Em um de seus mais célebres estudos - Inveja e gratidão -, Melanie KLEIN (1991, p.205-267) estabelece as relações entre o aparecimento prematuro da culpa, a voracidade e a inveja. No caso da biografia de Clarice, fica evidenciado em seus depoimentos o modo como relacionava o fato de não ter salvo sua mãe (e, portanto, como complemento imaginário, o de tê-la destruído) a um sentimento indelével de culpabilidade e ao desejo - sempre insatisfeito - de reparação.

32 No livro Felicidade clandestina.

33 Embora também como esforço incipiente, tentei em trabalho anterior investigar desdobramentos dessa opção radical na obra de Clarice Lispector, tomando como ponto de partida o romance A maçã no escuro. Ver MARTINS (1997). 
relativizado ou, até mesmo, justificado, tal é a sentença, no e por princípio exposta, previamente anunciada: "cem anos de perdão". Participa da cena do julgamento, ainda, como testemunha e cúmplice, alguém de quem se espera - ou se exige - participação e compreensão - o leitor: "Quem nunca roubou não vai me entender. E quem nunca roubou rosas, então, é que jamais poderá me entender. Eu, em pequena, roubava rosas."

A criança pobre tentará, mais uma vez, pela crença na potência do pensamento mágico, reduzir a distância, a diferença social, praticando a "brincadeira de essa casa é minha". A imaginação infantil garante temporariamente, no plano da fantasia, a disputa pela posse das inacessíveis propriedades das quais é privada. Mas a impossibilidade do acesso materializa-se como dura e concreta barreira (que não impede, entretanto, a fixidez do olhar cobiçoso e hipnotizado):

Eu e uma amiguinha brincávamos muito de decidir a quem pertenciam os palacetes. [...] Parávamos às vezes longo tempo, a cara imprensada nas grades, olhando.

Não satisfeita, porém, com a posse fantasiosa, elege uma "rosa apenas entreaberta cor-de-rosa vivo", passando a desejá-la, apesar da sempre presente inacessibilidade:

Fiquei feito boba, olhando com admiração aquela rosa altaneira que nem mulher feita ainda não era. $E$ então aconteceu: do fundo do meu coração, eu queria aquela rosa para mim. Eu queria, ah como eu queria. E não havia jeito de obtê-la. [...] No meio do meu silêncio e do silêncio da rosa, havia o meu desejo de possuí-la como coisa só minha. Eu queria poder pegar nela. Queria cheirá-la até sentir a vista escura de tanta tonteira de perfume.

$\mathrm{O}$ conto estrutura-se como depoimento confessional e memorialístico e, como nos outros dois anteriores, os sentimentos da cobiça, do orgulho e da inveja são condensados, agora para justificar o ato repetido de apropriação indébita: o roubo de rosas, sorrateiramente subtraídas das ostentosas residências das famílias ricas de Recife. A idéia proibida do furto sorrateiro logo é equacionada sob a forma de "plano" bem calculado, "friamente" elaborado, embora "cheio de paixão". Desta vez, não pediria ou esperaria um milagre; agiria, beneficiando-se com o ato de apropriação do que the era forçosamente imposto como alheio. Porém, o desejo, sempre renovável, vira hábito e vício. À inveja, ao 
orgulho, à cobiça, à gula e à vaidade, vem somar-se agora o roubo, como experiência - legítima e prazerosa - da infância. ${ }^{34}$

A posse da flor cobiçada - e na qual a menina se quer espelhada, já que rosa "altaneira" mesmo nem sendo "mulher feita ainda" - coincide com o processo de maturação sexual da garota de "corpo esguio", como num rito de passagem. Muito mais claramente do que em "Restos do carnaval", as imagens sensuais aqui proliferam. O perfume deixa a "vista escura" e causa "tonteira"; o sangue ritualmente brota e é levado à boca; tudo num movimento "de paixão" e sendo realizado durante "um século de coração batendo", "sempre com aquela glória que ninguém me tirava". O prazer propiciado pela ousadia de realizar transfere-se, finalmente, para outro objeto: as sensuais pitangas ${ }^{35}$. O conto termina com imagens que sugerem a masturbação, a menstruação e o defloramento imaginários:

A sebe era de pitangueira. [...] Então, olhando antes para os lados para ver se ninguém vinha, eu metia a mão por entre as grades, mergulhava-a dentro da sebe e começava a apalpar até meus dedos sentirem o úmido da frutinha. Muitas vezes na minha pressa, eu esmagava uma pitanga madura demais com os dedos que ficavam como ensangüentados. [...] Nunca ninguém soube. Não me arrependo: ladrão de rosas e de pitangas tem 100 anos de perdão. As pitangas, por exemplo, são elas mesmas que pedem para ser colhidas, em vez de amadurecer e morrer no galho, virgens. ${ }^{36}$

Finalmente, em um texto de configuração enigmática - $O$ manifesto da cidade, do volume de contos/crônicas Onde estivestes de noite -, Clarice Lispector revisita Recife, fitando-a inicialmente da

34 Inclusive, numa outra crônica, Clarice afirma, irada e categórica: "Não, não tenho pena dos que morrem de fome. A ira é o que me toma. E acho certo roubar para comer." (Dies Irae, idem, p.38). Em Morte de uma baleia (idem, p.127), a relação entre fome e crime é revisitada: ao saber que uma baleia encalhada na praia do Leblon fora retalhada ainda viva e que sua carne era vendida, a autora pensa, em tom de imprecação: "maldito seja aquele que a comerá por curiosidade, só perdoarei quem tem fome, aquela fome antiga dos pobres."

35 Ver, também, episódio intitulado As jabuticabas, in LOBATO, M., op. cit., p.36-39.

36 Reflexões sobre a relação entre culpa, punição, masturbação, puberdade e menstruação podem ser encontradas em Klein (1997, p.242 e ss.). 
janela de uma casa, em um "momento que não é grave". Tal como em um caleidoscópio ou mosaico, as imagens fragmentárias vão constituindo um quadro no qual se misturam lembranças do passado e as difíceis mudanças do presente. Como peças de um jogo lingüístico de raro efeito estilístico, pronomes possessivos e pessoais de primeira e segunda pessoas reforçam as marcas da perda e da irremediável distância (temporal e espacial), culminadas na imagem por excelência da obstaculização e do impedimento - a presença esmagadora da "pedra" (como homologia literária dos processos de reificação e alienação trazidos pela proeminência da forma-mercadoria):

Onde está a pedra que sinto? a pedra que esmagou a cidade. Na forma palpável das coisas. Pois esta é uma cidade realizada. Seu último terremoto se perde em datas. Estendo a mão e sem tristeza contorno de longe a pedra. Alguma coisa ainda escapa da rosa-dos-ventos. Alguma coisa se endureceu na seta de aço que indica o rumo de - Outra Cidade.

A cidade "traçada", planificada, urbanizada e "realizada" com "engenhosidade" é agora "outra", "deserta de mim". O esmagamento da cidade pela grande pedra soma-se às demais imagens apocalípticas $^{37}$, para figurar o endurecimento das relações e destacar o vazio da paisagem ruinosa e solitária, cujo sentido original se perdeu ("[...] qual é o teu sentido? Como é cavo este coração no peito da cidade. Procuro, procuro.").

Recife, confundida com Babilônia e/ou Jerusalém, constitui-se como as antecessoras pela combinação de declínio e esplendor, cidade cercada de potentes muralhas que justificam sua impenetrabilidade ${ }^{38} \mathrm{e}$ renovam, provocativamente, o convite à decifração, ao desvendamento e à leitura do que simultaneamente se oculta e revela:

Da mais alta muralha - olho. Procuro. Da mais alta muralha não recebo nenhum sinal. Daqui não vejo, pois tua clareza é impenetrável. Daqui não vejo mas sinto que alguma coisa está escrita a carvão numa parede. Numa parede desta cidade.

37 Como as da aparição do "Cavalo" de "cascos duros de pedra" Apocalipse 6 e 9; a da rosa-dos-ventos, que remete aos quatro cantos da Terra e aos quatro cavaleiros; e a do terremoto - Ap. 16. 


\section{REFERÊNCIAS BIBLIOGRÁFICAS}

CAMPOS, Maria do Carmo. Clarice Lispector e A vida danificada e Era uma vez um pássaro, meu Deus!: imagens da infância em Clarice Lispector. In A matéria prismada. Porto Alegre/São Paulo: Mercado Aberto/EDUSP, 1999 (p. 191-212).

KLEIN, Melanie. Amor, culpa e reparação e outros trabalhos (1921-1945). Trad. de André Cardoso. Rio de Janeiro: Imago, 1996.

KLEIN, Melanie. A Psicanálise de crianças. Trad. de Liana Pinto Chaves. Rio de Janeiro: Imago, 1997.

KLEIN, Melanie. Inveja e gratidão e outros trabalhos (1946-1963). Trad. de Liana Pinto Chaves (coord.). Rio de Janeiro: Imago, 1991.

LISPECTOR, Clarice. A descoberta do mundo. 2. ed.. Rio de Janeiro: Nova Fronteira, 1984.

LISPECTOR, Clarice. Felicidade clandestina. 5. ed.. Rio de Janeiro: Nova Fronteira, 1987.

LISPECTOR, Clarice. A hora da estrela. 9. ed.. Rio de Janeiro: Rocco, 1998.

LISPECTOR, Clarice. Uma aprendizagem ou O livro dos prazeres. 13. ed.. Rio de Janeiro: Rocco, 1998.

LOBATO, Monteiro. Reinações de Narizinho no reino das Águas Claras. São Paulo: Brasiliense, 1998.

MARTINS, Gilberto Figueiredo. As vigas de um heroísmo vago Três estudos sobre $A$ maçã no escuro. Dissertação de Mestrado. São Paulo: FFLCH/USP, 1997.

MARTINS, Gilberto Figueiredo. Alter(c)idades - Um exercício de escalas (Espaço público, modos de subjetivação e formas de sociabilidade na obra de Clarice Lispector). Tese de Doutorado. São Paulo: FFLCH/USP, 2002.

MEZAN, Renato. A vingança da esfinge. Ensaios de Psicanálise. 2. ed.. São Paulo: Brasiliense, 1995. 